\title{
Germ cell-somatic cell interactions during spermatogenesis
}

\author{
P. T. K. Saunders \\ MRC Human Reproductive Sciences Unit, Centre for Reproductive Biology, The Chancellors \\ Building, Little France Crescent, 49 Old Dalkeith Road, Edinburgh EH16 4SB, UK
}

\begin{abstract}
The adult testis has two essential functions, namely the synthesis and secretion of the steroid hormone testosterone and the production of mature spermatozoa. Germ cells undergo mitosis, meiosis and condensation (spermiation) in close association with Sertoli cells and in defined associations with each other within the seminiferous epithelium. Normal spermatogenesis and fertility are dependent upon paracrine interactions between the somatic cells (Sertoli, Leydig and peritubular) and the germ cells, and upon endocrine support from the pituitary gland. Evidence for paracrine interactions between somatic and germ cells has been gained from observations on the patterns of expression of proteins, studies on isolated cell populations, germ cell or Leydig cell ablation with toxicants, mouse mutants and transgenics, and more recently from germ cell transplantation.
\end{abstract}

\section{Introduction}

The process of spermatogenesis involves maturation of diploid spermatogonia into mature haploid spermatozoa and takes place within the seminiferous tubules of the testis. All the germ cells develop within the tubules in close association with Sertoli cells. The most compelling evidence for the importance of the complex cellular associations within the testis in maintaining male fertility is provided by our current inability to recapitulate the process in vitro. The purpose of this review is to consider briefly the cellular architecture of the testis as well as some of the evidence relating to the paracrine and endocrine influences and cell-cell interactions that contribute to normal somatic cell and germ cell function. New insights are being gained from studies using germ cell transplantation.

\section{Organization of spermatogenesis}

The organization of spermatogenesis within the seminiferous epithelium is essentially the same in all mammals and historically was characterized by histological observations that described defined germ cell associations occupying the circumference of the tubule crosssection (Leblond and Clermont, 1952). These characteristic germ cell associations occupy time and space within the seminiferous epithelium and have been categorized into specific 'stages' (for a review, see Sharpe, 1994). The number of stages identified varies and is a characteristic 
Table 1. Organization and duration of spermatogenesis in selected species

\begin{tabular}{lccl}
\hline Species & Number of stages & $\begin{array}{c}\text { Duration of spermatogenesis } \\
\text { (days) }\end{array}$ & \multicolumn{1}{c}{ Reference } \\
\hline Ram $^{\text {a }}$ & 6 or $8 ?$ & 49 & $\begin{array}{l}\text { Hochereau et al. (1964) } \\
\text { Wrobel et al. (1995) }\end{array}$ \\
Goat & 8 & 48 & Franca et al. (1999) \\
Bull & 12 & 54 & Wrobel et al. (1996) \\
Water buffalo & $6 ?$ & $?$ & Wrobel and Pawar (1992) \\
Rat & 14 & 52 & Clermont and Harvey (1965) \\
\hline
\end{tabular}

${ }^{a}$ The ram shows seasonal variation in the efficiency of spermatogenesis (Hochereau-de Reviers et al., 1985).

of that species (Table 1). For example, rats have 14 stages (Leblond and Clermont, 1952); rams have eight stages according to some reports (Hochereau et al., 1964) and six according to others (Wrobel el al., 1995); and bulls have 12 stages (Berndston and Desjardins, 1974). The spermatogenic 'cycle' is the sum of all the stages and the duration of the cycle is the time taken for a single germ cell to pass once through each of the stages; this also varies between species (Table 1). In all ruminants, the stages are arranged sequentially along the length of the seminiferous tubule; as a result, in any tubule cross-section only a single stage, defined by the germ cell associations within it, will be observed (for a review, see Sharpe, 1994). High power views of cross-sections through the seminiferous epithelium of the adult ram (Fig. 1a) and rat (Fig. 1b) are shown. The bulk of the cell nuclei present within the sections are those of the germ cells at different stages of maturation, with the most mature germ cells closest to the luminal surface. Sertoli cell nuclei are located close to the basement membrane. The cytoplasm of the Sertoli cells was immunostained with an antibody directed against sulphated glycoprotein 1 (Fig. 1b), a sphingolipid binding protein, (SGP-1; Collard et al., 1988); fine tracts of Sertoli cell cytoplasm can been seen extending through the whole depth of the epithelium between the different types of germ cell (arrowheads). The outer surface of the tubules is enclosed by a layer of contractile cells known as peritubular myoid cells; cells within the interstitium include the steroidogenically active Leydig cells, cells lining blood vessels, Leydig cell precursors and macrophages (Skinner, 1991).

\section{Germ cell maturation}

The testis develops from somatic cells within the genital ridge and germ cells that migrate into this region from the fetal extraembryonic membranes. Differentiation of the somatic cells is dependent upon expression of the testis determining gene SRY (sex-determining region of the $Y$ chromosome) (Swain and Lovell-Badge, 1999). Initiation of testis cord formation and detectable expression of anti-Mullerian hormone has been reported at day 42 of pregnancy in the testes of bovine fetuses (Vigier et al., 1983) and day 30 in testes of ovine fetuses (Sweeney et al., 1997). The fetal germ cells are first seen as a 'primordial' alkaline phosphatase-positive population (PGC) in the allantois and undergo migration to reach the genital area where they become associated with Sertoli cells to form testis cords. Once within the testis cords, the cells differentiate to form gonocytes (also called prespermatogonia), which initially proliferate, but then become quiescent (Wrobel, 2000). Mutations in a few genes affect the proliferation and migration of the phosphatase-positive population. For example, the c-kit receptor (see below) is expressed in the phosphatase-positive population, and mice that do not express a functional c-kit receptor have fewer germ cells due to reduced survival of migratory primordial germ cells (Besmer et al., 1993). 

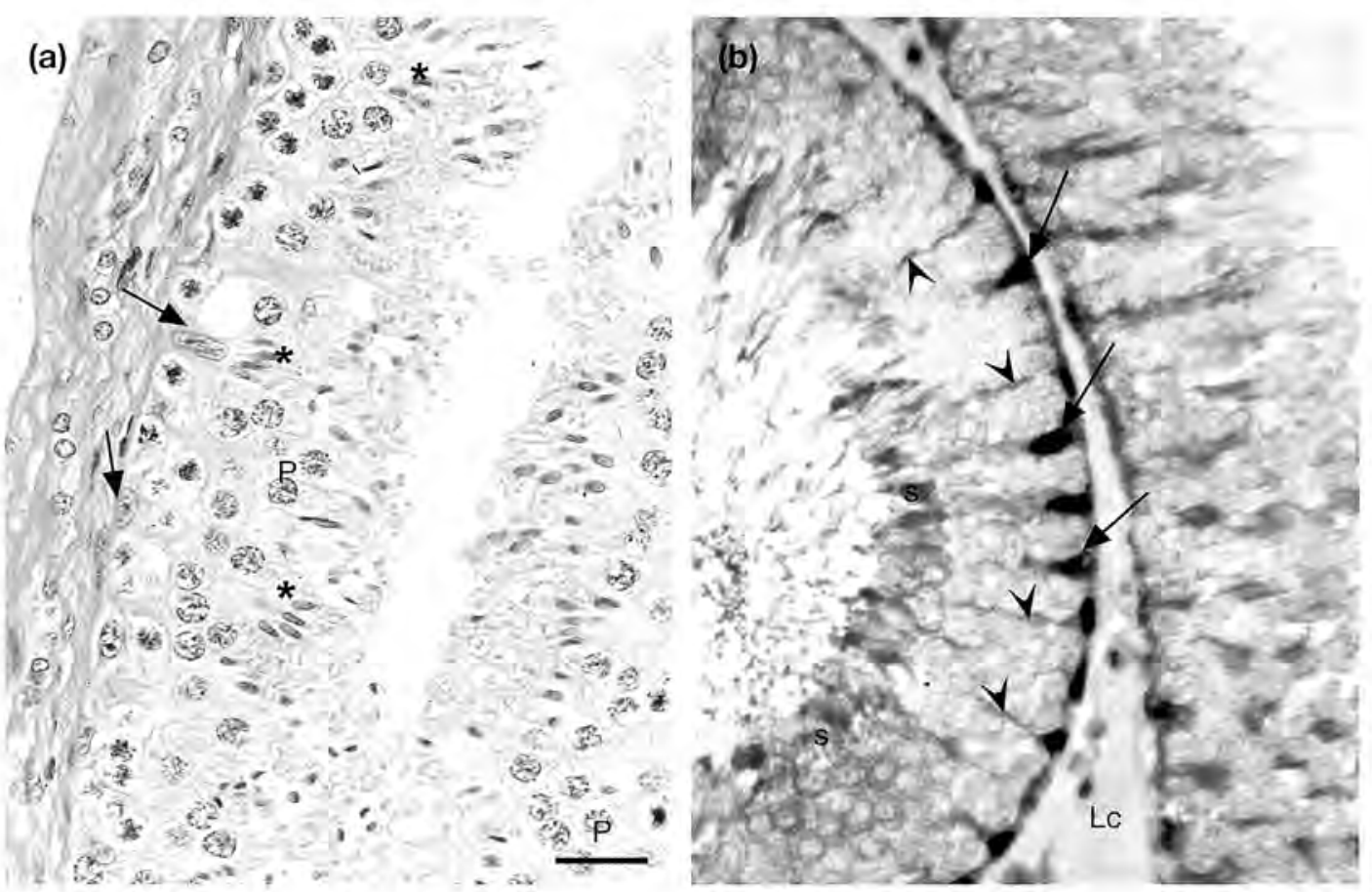

Fig. 1. Organization of the germ cells and Sertoli cells within the seminiferous epithelium. (a) Adult ram testis stained with haematoxylin and eosin. Note that the majority of nuclei are those of germ cells and that Sertoli cell nuclei are located close to the basement membrane (arrows). Multiple developmental stages of germ cells including large pachytene spermatocytes $(P)$ and groups of elongating spermatids ${ }^{*}$ ). (b) Adult rat testis immunostained for androgen receptor (AR, black nuclei, arrows) and sulphated glycoprotein 1 (SGP-1, red staining, cytoplasmic). Note that the cytoplasm of the Sertoli cell (arrowheads) extends from the base to the lumen of the seminiferous epithelium between the germ cells. s: spermatozoa surrounding the lumen of the seminiferous tubule; Lc: adult Leydig cells in interstitium, AR positive. Scale bar represents $50 \mu \mathrm{m}$.

In adult mammals, the maturation of germ cells is usually subdivided for convenience into a number of phases that include a spermatogonial-replicative phase, a meiotic phase and spermiogenesis (formation of the acrosome, nuclear condensation and cytoplasmic elimination) culminating in the release of the mature spermatozoa (spermiation) (summarized in Sharpe, 1994).

Spermatogonial stem cells form a self renewing population within the testis which can differentiate to form spermatogonial subtypes that become committed to the process of maturation (De Rooij, 2001). The number of times that the spermatogonial populations divide is different between species: in mice, 9-11 mitotic divisions occur resulting in significant amplification of the numbers of spermatogonia (De Rooij, 2001). In cows, the spermatogonial cells can be divided into three populations and, as in other species, strings of spermatogonia connected by cytoplasmic bridges can be identified in whole mount preparations (Wrobel, 2000). One way in which proliferating cells have been identified within the seminiferous epithelium is by immunostaining for proliferating cell nuclear antigen (PCNA). PCNA is expressed by cells in G1, S and G2M phases of the cell cycle (Wrobel et al., 1996). Immunostaining for PCNA can be used to highlight the distribution of proliferating spermatogonia and the meiotic phase pre-leptotene spermatocytes (see below) (Wrobel, 2000; Wrobel et al., 1996). In rats 

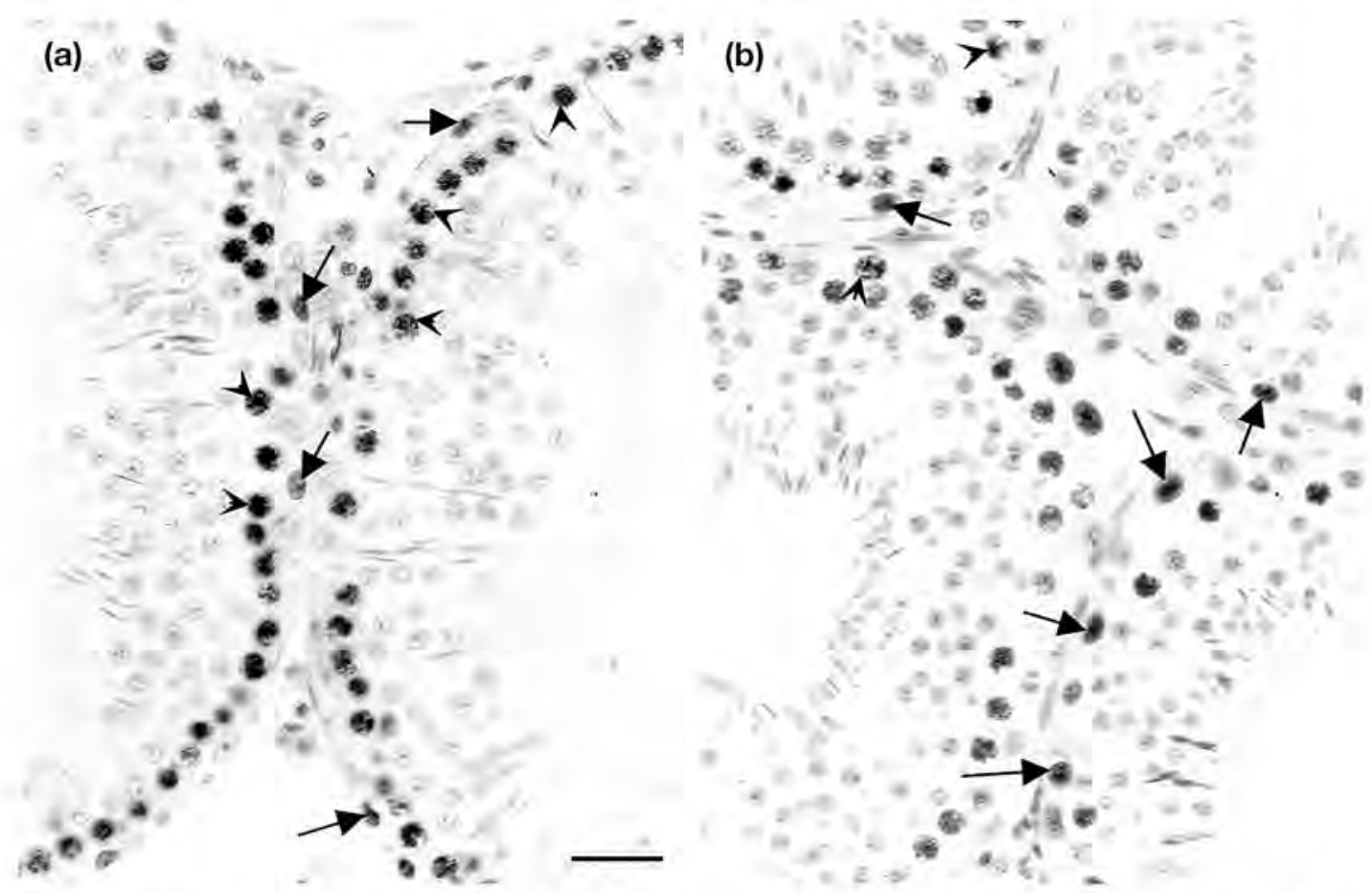

Fig. 2. Immunolocalization of proliferating cell nuclear antigen to germ cells within the seminiferous epithelium. (a) Adult rat testis and (b) adult ram testis. Note that immunopositive staining is found within the cell nuclei of spermatogonia (arrows) as well as more mature spermatocytes (arrowheads). In both species each cross-section is occupied by a single stage of spermatogenesis. Sertoli cell nuclei are not stained as these cells stop dividing as the first wave of germ cells develops. The scale bar represents $50 \mu \mathrm{m}$.

and rams (Fig. 2a,b), immunopositive cells at the same stage of development always occupy the entire circumference of the seminiferous epithelium, which is consistent with the 'segmental' organization of spermatogenesis. A different arrangement known as 'helical' occurs in some but not all primates, and in man (Sharpe, 1994).

The final mitotic division of the B type spermatogonia (De Rooij, 2001) gives rise to cells that enter a lengthy meiotic prophase as pre-leptotene spermatocytes. Thereafter, spermatocytes progress through leptotene, zygotene and pachytene phases of meiosis (all the spermatocytes are named according to the phase of meiosis through which they are progressing). At the end of meiotic prophase, spermatocytes undergo the final meiotic divisions to form haploid spermatids.

Thereafter, the spermatids embark on the process of spermiogenesis during which the nucleus of the germ cell is remodelled and compacted into the form found in the mature spermatozoa. The net result of DNA compaction during spermiogenesis is that sperm DNA occupies only $5 \%$ of the space of that seen in somatic cells (Ward and Coffey, 1991). Facilitation of this process is achieved in the following way. Somatic histones are replaced sequentially by testis-specific isoforms, transition proteins TP1 (Kremling et al., 1989) and TP2, and finally, by small, highly basic protamines two genes of which have been identified in most species. The importance of the timed expression of protamines and their incorporation into the mature spermatozoon is highlighted by studies in mice in which targeted disruption 
of protamines 1 and 2 has shown that a decrease in either protamine disrupts formation of a normal spermatozoa (Cho et al., 2001). The final stage of the process is spermiation when the mature spermatozoa are released from the Sertoli cells into the lumen of the seminiferous epithelium. This is a complex process involving a progressive loss of adhesive junctions and is poorly understood.

\section{Endocrine support for spermatogenesis}

Testicular function and normal fertility are dependent upon endocrine (extratesticular) and paracrine (intratesticular) factors. The primary endocrine hormones are the gonadotrophins $\mathrm{LH}$ and FSH which are synthesized and secreted by the pituitary gland. Gonadotrophin receptors are expressed only by somatic cells within the testis; the $\mathrm{LH}$ receptors are present on Leydig cells and the FSH receptors on Sertoli cells. Synthesis of testosterone by adult Leydig cells is stimulated by LH (Moyle and Ramachandran, 1973). Several studies have demonstrated that loss of pituitary hormones results in loss of germ cells (for a review, see McLachlan et al., 2002) and the hypogonadal mutant mice (hpg) which has only very low endogenous circulating concentrations of gonadotrophins (Cattanach et $a I_{+}, 1977$ ) are completely infertile. For example, in hypophysectomized adult rats, germ cell loss occurs first at day 6 after surgery and is associated with a reduction in the diameter of the seminiferous tubules (Ghosh et al., 1992). Some male ruminants, including rams and stags, show a cyclical variation in the efficiency of spermatogenesis that is driven by changes in the stimulation of the testis by gonadotrophins (Blottner et al., 1996; Lincoln et al., 1990). In these species, stimulation of testosterone synthesis from the Leydig cells caused by increases in frequency, amplitude and duration of $\mathrm{LH}$ release from the pituitary gland (Lincoln, 1976) results in development of androgen stimulated secondary sexual characteristics.

Separating the roles played by FSH and L.H in spermatogenesis has proved challenging and has been confounded by problems with interpretation of cellular changes in some in vivo models and concerns over the purity of non-recombinant proteins. Studies on mice with targeted ablation of gonadotrophins, or their receptors, have allowed new and detailed examination of the contributions of LH and FSH to spermatogenesis (Krishnamurthy et al., 2000; Allan et al., 2001). Briefly, the amount of gonadal development in $\mathrm{LH}$ receptor knockout mice (LURKO) seen at birth was similar to that of control mice, but in adulthood these mice had poorly developed seminiferous tubules with sporadic germ cells up to and including round spermatids (Zhang et al., 2001). Leydig cells were poorly differentiated and it is assumed that the limited germ cell development was stimulated by FSH (Zhang et al., 200T). Young male FSH receptor knock-out mice (FORKO; Krishnamurthy et al., 2000) have underdeveloped testis and a $50 \%$ reduction in the number of Sertoli cells, consistent with previous observations that FSH stimulates Sertoli cell replication early in life. The FORKO mice experience delayed puberty with postponement in the formation of round spermatids and, surprisingly, adult males also have reduced serum testosterone concentrations despite normal circulating LH concentrations, indicating disturbances in Sertoli-Leydig cell communication. Adult FORKO males have reduced fertility and aberrant spermatozoa with inadequate DNA compaction (Krishnamurthy et al., 2000). Allan et al. (2001) developed a new model to examine the impact of FSH on the process of spermatogenesis by combining transgenic expression of FSH in the gonadotrophin deficient background of the hpg mouse. The testis size of hpg mice with high concentrations of FSH was increased and the testis contained round spermatids and a few elongated spermatids. These results demonstrate that in the absence of testosterone, FSH simulation of Sertoli cells can facilitate completion of meiosis and initiation, but not completion, of spermiogenesis. 


\section{Germ cell-soma interactions in adulthood}

The number of germ cells that are supported by an individual Sertoli cell varies between species and contributes to the efficiency of the process of spermatogenesis, that is, the number of mature elongate spermatids per Sertoli cell (Sharpe, 1994). Paracrine regulation of spermatogenesis involves interaction between all the major types of cell within the testis (Skinner, 1991) and a few of these are highlighted below.

\section{Leydig cell products}

One of the most important interactions is between Leydig cells and Sertoli cells; this has been demonstrated most elegantly in rats by selective ablation of Leydig cells after treatment with the toxicant ethane dimethane sulphonate (Kerr et al., 1985). Removal of Leydig cells by ethane dimethane sulphonate results in degeneration of germ cells in a stage-dependent manner over time (discussed in detail in Sharpe, 1994). The main secretory product of the Leydig cell is testosterone, and studies have shown that the concentrations of testosterone within the testis far exceed concentrations within the peripheral circulation (Sharpe et al., 1988; Sharpe, 1994). Several studies have examined how testosterone might influence germ cell development and survival. Notably, studies using immunohistochemistry have established that the androgen receptors which bind testosterone are expressed in Sertoli cell and peritubular cell nuclei but are not present in germ cells (Fig. 1b) (Saunders et al., 1996; Goyal et al., 1997). This finding has led to a number of studies to establish which Sertoli cell products could be modulated by androgens as these might be key to our understanding of the ways in which the Sertoli cell passes on the androgenic signal coming from the Leydig cells to the germ cells. New data from gene array experiments indicate that testosterone may downregulate twice as many genes as it upregulates within the Sertoli cell (Griswold, 2002), but to date, it is not known how testosterone influences germ cell function.

Leydig cells also contain aromatase cytochrome P450 (Turner et al., 2002), the enzyme that is required for conversion of androgens to oestrogens. Low expression of aromatase has also been detected in round and elongating spermatids and in spermatozoa (Turner et al., 2002). In mice that are unable to synthesize oestrogens due to targeted ablation of aromatase P450, round spermatids undergo apoptosis and, thus, fail to differentiate into mature, elongated spermatids; this lesion appears to arise at between 18 weeks and 1 year of age (Robertson et al., 1999). Two structurally related subtypes of oestrogen receptor (ER), commonly known as $\alpha$ $(E R \alpha, N R 3 A 1)$ and $\beta(E R \beta, N R 3 A 2)$ have been identified in mammals (Nilsson et al., 2001). Differences in the pattern of expression of ER $\alpha$ in the testes occurs between species with detectable ER $\alpha$ protein within Leydig cells of rodents (Fisher et al., 1997), but no ER $\alpha$ in any type of cell in the testes of humans, primates (Saunders et al., 2001) and goats (Goyal et al. 1997). ER $\beta$ protein has been immunolocalized to the nuclei of Sertoli cells, Leydig cells and peritubular myoid cells as well as some, but not all, germ cells (Saunders et al., 2001). The presence of ER $\beta$ within germ cells raises the possibility that oestrogens could have a direct effect on germ cell function and some support for this idea has come from investigations showing that oestrogen may act as a germ cell survival factor (Pentikainen et al., 2000); germ cell maturation has been induced in hpg mice treated with oestrogens (Ebling et al., 2000). Studies on mice have shown that the loss of fertility in males with targeted disruption of the $E R \propto$ gene is due to a defect in fluid resorption (Eddy et al., 1996) and is not associated with direct effects on germ cells. Mice in which the functional integrity of the ER $\beta$ gene has been disrupted (Dupont et al., 2000) are fertile and, although the fertility of male mice lacking both $E R \alpha$ and ERß (Dupont et al., 2000) is compromised, their phenotype appears to resemble that 
of the ER $\alpha$ KO. Further studies are required to determine whether oestrogens are paracrine, autocrine (or paracrine and autocrine) regulators of germ cell function.

\section{Sertoli cell products}

Secretory products of Sertoli cells have been identified by many groups. One deficiency of some of the studies is that they have been conducted on cells isolated from immature rodents that have never been exposed to mature germ cells in vivo. A comprehensive list of the factors synthesized by the Sertoli cell is beyond the scope of this review and, therefore, a few examples have been selected to illustrate specific types of interaction and are discussed below. Additional information can be found in reviews by Skinner (1991, 1993), Sharpe (1994) and Griswold (1995).

Sertoli cells synthesize and secrete inhibins, activins and follistatins (Roberts et al., 1989; de Kretser et al., 2001). Inhibin is a glycoprotein that can exist as two heterodimeric forms consisting of an $\alpha$ chain and one of two types of $\beta$ chain; activins are formed as dimers of the two $\beta$ chains (de Kretser et al., 2001). Inhibin acts as an endocrine hormone and was originally identified on the basis of its ability to act as a negative regulator of $\mathrm{FSH}$ secretion by the pituitary gland. After castration, concentrations of inhibin in the peripheral circulation decrease and those of FSH increase (Ishida et al, 1990). In most species examined so far there is a positive relationship between concentrations of inhibin B produced by the testis and the number of Sertoli cells, and secretion of inhibin by immature Sertoli cells in vitro can be stimulated by FSH. Other data show that adult Leydig cells can also produce inhibin and that Leydig cell products may play a role in modulating expression of the inhibin $\alpha$ subunit by Sertoli cells (for a review, see de Kretser et al, 2001). There are conflicting data on the cellular sites of activin subunits but bioassay data support the production of activin A by Sertoli cells (de Winter et al., 1993). Follistatins act as activin-binding proteins and a role for activin supporting germ cell maturation can be inferred from the observation that overexpression of follistatins in mice results in spermatogenic arrest (Guo etal., 1998). Activin has been proposed to have paracrine effects on germ cell maturation at several points including transformation of gonocytes into spermatogonia, stimulation of spermatogonial proliferation and maintenance of mitochrondrial morphology of germ cells beyond the pre-leptotene stage (for a review, see de Kretser et al., 2001).

One of the most well researched aspects of germ cell-Sertoli cell interaction is that of c-kit-kit ligand. In species investigated so far, including rodents, primates and ruminants, c-kit receptors are expressed on adult germ cells (type A spermatogonia up to pachytene spermatocytes) (Loveland and Schlatt, 1997; Roelants et al., 2002). Conversely, the ligand for the receptor, which is known as kit ligand, stem cell factor or Steel factor, is synthesized by the Sertoli cells in both a membrane-bound and soluble form (Besmer et al, 1993). Evidence from studies in vivo and in vitro indicates that c-kit-kit ligand expression may be important for regulation of spermatogonial cell proliferation and differentiation (De Rooij, 2001) and adhesive interactions between germ cells and Sertoli cells. Studies in which the glial cell-derived neurotrophic factor (GDNF) has been under-or overexpressed in mice have concluded that GDNF, a product of Sertoli cells, plays a role in regulation of self renewal of spermatogonial stem cells; mice with targeted overexpression of GDNF develop testicular germ cell tumours (Meng et al., 2001).

The importance of the structural support provided by the Sertoli cells is often overlooked. The development of basally located tight junctions between Sertoli cells at puberty is essential for the formation of a selective permeability barrier known as the 'blood-testis barrier' which allows the development of a specialized luminal environment within the seminiferous 
epithelium (Dym and Fawcett, 1970). Our understanding of the molecular basis of the physical interaction between germ cells and Sertoli cells was advanced recently by studies on mice containing a targeted ablation for the enzyme encoding alpha-mannosidase Ilx (Akama et al., 2002). In these mice, germ cells failed to adhere to the Sertoli cells correctly and were released prematurely, and as a result most of the mice were infertile (Akama et al., 2002).

\section{Germ cell products}

Studies in vivo on rats in which specific germ cell populations are removed by toxicants, such as methoxyacetic acid (Bartlett et al., 1988) have demonstrated that the complement of germ cells in individual seminiferous tubules can modulate Sertoli cell protein synthesis and production of seminiferous tubule fluid (McKinnell and Sharpe, 1992). Specific Sertoli cell proteins regulated by the presence of selected germ cells in vivo include inhibin (Allenby et al., 1991), transferrin (Maguire et al., 1997) and cyclic protein 2 (Maguire et al., 1993). The molecules regulating this germ cell-Sertoli cell interaction have yet to be identified.

\section{Germ cell transplantation}

Spermatogonial stem cell transplantation is a novel method, originally developed by Ralph Brinster and colleagues, that involves the transfer of mixed or purified populations of germ cells from the testis of a donor animal into that of a recipient (Brinster and Zimmermann, 1994). Several groups have demonstrated that the spermatogonial stem cells from the donor testis can repopulate the testis of germ cell deprived recipients and re-initiate the process of spermatogenesis (for a review, see McLean et al., 2001). For example, using reciprocal transplantation of germ cells from the Steel (kit ligand deficient) and W (c-kit deficient) mice, investigators have shown that kit ligand is essential for maintenance of differentiated spermatogonia and that transplantation of spermatogonial stem cells from an infertile Steel donor to a kit ligand positive testicular environment can restore fertility and result in progeny with the genetic makeup of the infertile donor male (Ogawa et al., 2000; Ohta et al,, 2000), One of the most remarkable findings reported using this technique involved transplantation of rat germ cells into the testis of an immunosuppressed mouse. Not only were mature rat spermatozoa produced but also within the testis the rat germ cells developed with timings characteristic of rat spermatogenesis (52 days); in the same testis mouse germ cells developed in 35 days (Franca et al., 1998). These findings show both the remarkable ability of the Sertoli cell to function to support different germ cells and argue against a role for the Sertoli cell in determining the timing of germ cell development. Other xenograft transplantations (dog, hamster and primate) have been less successful (Dobrinski et al., 1999; Nagano et al., 2001). Transplantation has also been attempted in bull, monkey and human testis with limited success (Schlatt et al., 1999).

\section{Conclusions}

The complexity of the cellular architecture of the mammalian testis has made it difficult to determine the specific paracrine, autocrine and endocrine interactions that are essential for the maintenance of normal fertility. Most of the progress over the last few years has come from studies in rodent model systems including the use of selective cell ablation, hormonal manipulation, transgenic knockouts and more recently germ cell transplantation. Studies on species other than rodents have been less comprehensive and continue to present new challenges. 


\section{References}

Akama TO, Nakagawa H, Sugihara K, Narisawa S, Ohyama C, Nishimura S, O'Brien DA, Moremen KW, Millan JL and Fukuda MN (2002) Germ cell survival through carbohydrate-mediated interaction with Sertoli cells Science 295 124-127

Allan CM, Haywood M, Swaraj S et al. (2001) A novel transgenic model to characterize the specific effects of follicle-stimulating hormone on gonadal physiology in the absence of luteinizing hormone actions Endocrinology 142 2213-2220

Allenby G, Foster PMD and Sharpe RM (1991) Evidence that secretion of immunoactive inhibin by semini. ferous tubules from the adult rat testis is regulated by specific germ cell types: correlation between in vivo and in vitro studies Endocrinology 128 $467-476$

Bartlett IMS, Kerr JB and Sharpe RM (1988) The selective removal of pachytene spermatocytes using methoxy acetic acid as an approach to the study in vivo of paracrine interactions in the testis Journal of Andrology $931-40$

Berndston WE and Desjardins C (1974) The cycle of the seminiferous epithelium and spermatogenesis in the bovine testis American Journal of Anatomy 140 $167-180$

Besmer P, Manova K, Duttlinger R, Huang EJ, Packer A, Gyssler C and Bachvarova RF (1993) The kitligand (steel factor) and its receptor c-kit/W: pleiotropic roles in gametogenesis and melanogenesis Development Supplement 1 125-137

Blottner S, Hingst O and Meyer HH (1996) Seasonal spermatogenesis and testosterone production in roe deer (Capreolus capreolus) Journal of Reproduction and Fertility $\mathbf{1 0 8} 299-305$

Brinster R and Zimmermann J (1994) Spermatogenesis following male germ cell transplantation Proceedings National Academy of Sciences USA $9411298-$ 11302

Cattanach BM, Iddon CA, Charlton HM, Chiappa SA and Fink G (1977) Gonadotrophin-releasing hormone deficiency in a mutant mouse with hypogonadism Nature $269338-340$

Cho $\mathrm{C}$, Willis WD, Goulding EH, Jung-Ha $\mathrm{H}$, Choi $\mathrm{YC}$, Hecht NB and Eddy EM (2001) Haploinsufficiency of protamine- 1 or -2 causes infertility in mice Nature Genetics 28 82-86

Clermont Y and Harvey SC (1965) Duration of the cycle of the seminiferous epithelium in normal, hypophysectomized and hypophysectomized-hormone treated albino rats Endocrinology $7680-89$

Collard MW, Sylvester SR, Tsuruta JK and Griswold MD (1988) Biosynthesis and molecular cloning of sulphated glycoprotein 1 secreted by rat Sertoli cells: sequence similarity with the 70-kilodalton precursor to Sulphatide/ $\mathrm{M} 1$ activator Biochemistry 27 4557-4564 de Kretser DM, Loveland KL, Meehan T, O'Bryan MK, Phillips DJ and Wreford NG (2001) Inhibins, activins and follistatin: actions on the testis Molecular and Cellular Endocrinology $18087-92$

De Rooij DG (2001) Proliferation and differentiation of spermatogonial stem cells Reproduction 121 $347-354$

de Winter JP, Vanderstichele HM, Timmerman MA, Blok LJ, Themmen AP and de Jong FH (1993) Activin is produced by rat Sertoli cells in vitro and can act as an autocrine regulator of Sertoli cell function Endocrinology 132 975-982

Dobrinski I, Avarbock MR and Brinster RL (1999) Transplantation of germ cells from rabbits and dogs into mouse testes Biology of Reproduction 61 1331-1339

Dupont S, Krust A, Gansmuller A, Dierich A, Chambon $P$ and Mark M (2000) Effect of single and compound knockouts of estrogen receptors $\alpha(E R \alpha)$ and $\beta$ (ER $\beta)$ on mouse reproductive phenotypes Development $127 \cdot 4277-4291$

Dym M and Fawcett DW (1970) The blood-testis barrier in the rat and the physiological compartmentation of the seminiferous epithelium Biology of Reproduction 3 308-326

Ebling FJP, Brooks AN, Cronin AS, Ford $\mathrm{H}$ and Kerr JB (2000) Estrogenic induction of spermatogenesis in the hypogonadal mouse Endocrinology 141 2861-2869

Eddy EM, Washburn TF, Bunch DO, Goulding EH, Gladen BC, Lubahn DB and Korach KS (1996) Targeted disruption of the estrogen receptor gene in male mice causes alteration of spermatogenesis and infertility Endocrinology $1374796-4805$

Fisher J, Millar MR, Majdic G, Saunders PTK, Fraser HM and Sharpe RM (1997) Immunolocalisation of oestrogen receptor- $\alpha(E R \alpha)$ within the testis and ex current ducts of the rat and marmoset monkey from perinatal life to adulthood lournal of Endocrinology $153485-495$

Franca L, Ogawa T, Avarbcok M, Brinster R and Russell L (1998) Germ cell genotype controls cell cycle during spermatogensis in the rat Biology of Reproduction $591371-1377$

Franca LR, Becker-Silva SC and Chiarini-Garcia H (1999) The length of the cycle of seminiferous epithelium in goats (Capra hircus) Tissue Cell $31274-280$

Ghosh S, Bartke A, Grasso P, Reichert LE] and Russell LD (1992) Structural manifestations of the rat Sertoli cell to hypophysectomy: a correlative morphometric and endocrine study Endocrinology 131 485-497

Goyal HO, Bartol FF, Wiley AA and Neff CW (1997) Immunolocalization of receptors for androgen and estrogen in male caprine reproductive tissues: unique distribution of estrogen receptors in efferent ductule epithelium Biology of Reproduction 56 90-101 
Griswold MD (1995) interactions between germ cells and Sertoli cells in the testis Biology of Reproduction $52211-216$

Griswold MD (2002) Control of spermatogenesis via Sertoli cells. In Testicular Tangrams pp 75-84 Eds FFG Rommerts and KJ Teerds. Springer: Berlin

Guo Q, Kumar TR, Woodruff T, Hadsell LA, DeMayo FJ and Matzuk MM (1998) Overexpression of mouse follistatin causes reproductive defects in transgenic mice Molecular Endocrinology 12 96-106

Hochereau MT, Courot M and Ortavant R (1964) Marquage des cellules germinales du belier et du taureau per injection de thymidine tritiee dans l'artere spermatique Annals of Biology, Animals, Biochemistry and Biophysics 2 157-159

Hochereau-de Reviers MT, Perreau C and Lincoln GA (1985) Photoperiodic variations of somatic and germ cell populations in the Soay ram testis Journal of Reproduction and Fertility 74 329-334

Ishida $H$, Tashiro $H$, Watanabe $M$, Fujii N, Yoshida $H$, Imamura K, Minowada S, Shinohara M, Fukutan K and Aso Y (1990) Measurement of inhibin concentrations in men: study of changes after castration and comparison with androgen levels in testicular tissue, spermatic venous blood and peripheral venous blood Journal of Clinical Endocrinology and Metabolism 70 1019-1022

Kerr JB, Donachie K and Rommerts FFG (1985) Selective destruction and regeneration of rat Leydig cells in vivo. A new method for the study of seminiferous tubular-interstitial tissue interaction Cell and Tissue Research 242 145-156

Kremling $H$, Luerssen $H$, Adham IM, Klemm $U$, Tsaousidou S and Engel W (1989) Nucleotide sequences and expression of cDNA clones for boar and bull transition protein 1 and its evolutionary conservation in mammals Differentiation 40 184-190

Krishnamurthy $\mathrm{H}$, Danilovich N, Morales CR and Sairam MR (2000) Qualitative and quantitative decline in spermatogenesis of the follicle-stimulating hormone receptor knockout (FORKO) mouse Biology of Reproduction 62 1146 1159

Leblond CP and Clermont Y (1952) Definition of the stages of the cycle of the seminiferous epithelium in the rat Annals of the New York Academy of Sciences $55548-573$

Lincoln GA (1976) Seasonal variation in the episodic secretion of luteinizing hormone and testosterone in the ram Journal of Endocrinology $69213-226$

Lincoln GA, Lincoln CE and McNeilly AS (1990) Seasonal cycles in the blood plasma concentration of $\mathrm{FSH}$, inhibin and testosterone, and testicular size in rams of wild, feral and domesticated breeds of sheep Journal of Reproduction and Fertility 88 623-633

Loveland KL and Schlatt S (1997) Stem cell factor and c-kit in the mammalian testis: lessons originating from Mother Nature's gene knockouts Journal of Endocrinology 153 337-344
McKinnell C and Sharpe R (1992) The role of specific germ cell types in modulation of secretion of androgen-regulated proteins (ARPs) by stage VI-VIII seminiferous tubules from the adult rat Molecular and Cellular Endocrinology 83 219-231

McLachlan RI, O'Donnell L, Meachem SJ, Stantón PG, de Kretser DM, Pratis K and Robertson DM (2002) Identification of specific sites of hormonal regulation in spermatogenesis in rats, monkeys and man Recent Progress in Hormone Research 57 149-179

McLean DJ, Johnston DS, Russell LD and Griswold MD (2001) Germ cell transplantation and the study of testicular function Trends in Endocrinology and Metabolism 12 16-21

Maguire SM, Millar M, Sharpe RM and Saunders PTK (1993) Stage-dependent expression of mRNA for cyclic protein-2 during spermatogenesis is modulated by elongate spermatids Molecular and Cellular Endocrinology 94 79-88

Maguire SM, Millar MR, Sharpe RM, Gaughan J and Saunders PTK (1997) Investigation of the potential role of the germ cell complement in control of the expression of transferrin mRNA in the prepubertal and adult rat lestis Journal of Molecular Endocrinology $1967-77$

Meng X, de Rooij DG, Westerdahl K, Saarma M and Sariola $\mathbf{H}$ (2001) Promotion of seminomatous tumors by targeted overexpression of glial cell line-derived neurotrophic factor in mouse testis Cancer Research $613267-3271$

Moyle WR and Ramachandran J (1973) Effect of LH on steroidogenesis and cyclic AMP accumulation in rat Leydig cell preparations and mouse tumor Leydig cells Endocrinology $93127-134$

Nagano M, McCarrey JR and Brinster RL (2001) Primate spermatogonial stem cells colonize mouse testes Biology of Reproduction 64 1409-1416

Nilsson S, Makela S, Treuter E, Tujague M, Thomsen J, Andersson G, Enmark E, Pettersson K, Warner M and Gustafsson JA (2001) Mechanisms of estrogen action Physiological Reviews 81 1535-1565

Ogawa T, Dobrinski I, Avarbock MR and Brinster RL (2000) Transplantation of male germ line stem cells restores fertility in infertile mice Nature Medicine 6 29-34

Ohta $H$, Yomogida $K$, Dohmae $K$ and Nishimune $Y$ (2000) Regulation of proliferation and differentiation in spermatogonial stem cells: the role of c-kit and its ligand SCF Development 127 2125-2131

Pentikainen V, Erkkila K, Suomalainen L, Parvinen $\mathbf{M}$ and Dunkel L (2000) Estradiol acts as a germ cell survival factor in the human testis in vitro. Journal of Clinical Endocrinology and Metabolism 85 2057-2067

Roberts V, Meunier H, Sawchenko PE and Vale W (1989) Differential production and regulation of inhibin subunits in rat testicular cell types Endocrinology 125 $2350-2359$ 
Robertson K, O'Donnell L, Jones M, Meachem S, Boon W, Fisher C, Graves K, MacLachlan R and Simpson E (1999) Impairment of spermatogenesis in mice lacking a functional aromatase (CYP19) gene Proceedings National Acaderny of Sciences USA 96 7986-7991

Roelants H, Schneider F, Goritz F, Streich I and Blottner S (2002) Seasonal changes of spermatogonial proliferation in roe deer, demonstrated by flow cytometric analysis of c-kit receptor, in relation to follicle-stimulating hormone, luteinizing hormone and testosterone Biology of Reproduction 66 305-312

Saunders PTK, Millar MR, Majdic G, McLaren TT, Bremner WJ, Grigor KM and Sharpe RM (1996) Testicular androgen receptor protein: distribution and control of expression. In Cellular and Molecular Regulation of Testicular Cells. pp 213-229 Ed. CDesjardins. Springer Verlag: Berlin

Saunders PTK, Sharpe RM, Williams K, Macpherson S, Urquhart H, Irvine DS and Millar MR (2001) Differential expression of oestrogen receptor alpha and beta proteins in the testes and male reproductive system of human and non-human primates Molecular Human Reproduction 7 227-236

Schlatt S, Rosiepen G, Weinbauer GF, Rolf C, Brook PF and Nieschlag E (1999) Germ cell transfer into rat, bovine, monkey and human testes Human Reproduction 14 144-150

Sharpe RM (1994) Regulation of Spermatogenesis. In The Physiology of Reproduction 2nd Edn. pp $1363-$ 1434 Eds E Knobil and JD Neill. Raven Press: New York

Sharpe RM, Donachie K and Cooper I (1988) Reevaluation of the intratesticular level of testosterone required for quantitative maintenance of spermatogenesis in the rat Journal of Endocrinology 117 $19-26$

Skinner MK (1991) Cell-cell interactions in the testis Endocrine Reviews 12 45-77

Skinner MK (1993) Sertoli cell-peritubular myoid cell interactions. In The Sertoli Cell pp 493-508. Eds LD Russell and MD Griswold. Cache River Press: Clearwater, Florida
Swain A and Lovell-Badge R (1999) Mammalian sex determination: a molecular drama Genes and Development 13 755-767

Sweeney T, Saunders PT, Millar MR and Brooks AN (1997) Ontogeny of anti-Mullerian hormone; 3 beta-hydroxysteroid dehydrogenase and androgen receptor expression during ovine total gonadal development fournal of Endocrinology $15327-32$

Turner K], Macpherson S, Millar MR, McNeilly AS, Williams K, Cranfield M, Groome NP, Sharpe RM, Fraser HM and Saunders PT (2002) Development and validation of a new monoclonal antibody to mammalian aromatase Journal of Endocrinology $\mathbf{1 7 2}$ $21-30$

Vigier B, Tran D, du Mesnil du Buisson F, Heyman Y and Josso $N$ (1983) Use of monoclonal antibody techniques to study the ontogeny of bovine antiMullerian hormone Journal of Reproduction and Fertility $69207-214$

Ward SW and Coffey DS (1991) DNA packaging and organization in mammalian spermatozoa: comparison with somatic cells Biology of Reproduction 44 569-574

Wrobel KH (2000) Prespermatogenesis and spermatogoniogenesis in the bovine testis Anatomy and Embryology 202 209-222

Wrobel KH and Pawar HS (1992) Quantitative morphology of the testicular tubular epitbelium in the water buffalo (Bubalus bubalis) Andrologia $\mathbf{2 4}$ 63-68

Wrobel KH, Reichold J and Schimmel M (1995) Quantitative morphology of the ovine seminiferous epithe lium Anatomy Anz 177 19-32

Wrobel KH, Bickel D and Kujat R (1996) Immunohistochemical study of seminiferous epithelium and adult bovine testis using monoclonal antibodies against Ki-67 protein and proliferating cell nuclear antigen (PCNA) Cell and Tissue Research 283 $191-201$

Zhang FP, Poutanen M, Wilbertz I and Huhtaniemi I (2001) Normal prenatal but arrested postnatal sexual development of luteinizing hormone receptor knockout (LuRKO) mice Molecular Endocrinology 15 172-183 